\title{
Determination of individual bile acids in biological fluids by thin-layer chromatography and fluorimetry
}

\author{
D. PANVEliWALla, B. LEWIS, I. D. P. WOOTTON, AND S. TABAQCHALI
} From the Department of Chemical Pathology and the Medical Research Council Group on Intestinal Malabsorption, Department of Medicine, Royal Postgraduate Medical School, London

SYNOPSIS A method is described for the separation and determination of individual bile $\underset{-}{\triangle}$ acids in serum and in intestinal contents, employing thin-layer chromatography and fluori-z metry. The mean recovery from intestinal juice was $94 \%$ and from serum $82 \%$.

Normal values for the individual bile acids of serum and examples of clinical applications $\vec{\theta}$ of the method are given.

Several procedures have been described for determining individual bile acids in biological fluids, including column and paper chromatography (Rudman and Kendall, 1957; Sjövall, 1959; Wootton and Osborn, 1960), thin-layer chromatography (Kottke, Wollenweber, and Owen, 1966) and gas-liquid chromatography. Despite the refinement of gas-chromatography analysis for the estimation of free bile acids (Sandberg, Sjövall, Sjövall, and Turner, 1965; Roovers, Evrard, and Vanderhaeghe, 1968) the measurement of individual conjugated bile acids by this method requires preliminary separation of glycine and taurine conjugates and of free bile acids, followed by hydrolysis of the conjugates.

Requiring data on conjugated as well as free bile acids in large numbers of samples, we have developed a method using thin-layer chromatography and fluorimetry. Unlike ultraviolet spectrophotometry, fluorimetry provides a method for determining lithocholic acid; it is also of great sensitivity.

Thin-layer chromatography has been found to provide satisfactory resolution of the major conjugated and free bile acids for quantitation.

\section{Methods}

PURIFICATION OF SILICIC ACID

Untreated silicic acid (Kieselgel G. Merck \& Co) gives a high fluorescent blank. It is treated by allowing it to stand overnight in $20 \mathrm{~N}$ sulphuric $\frac{\circ}{\mathbb{D}}$ acid, then washing on a sintered glass funnel with distilled water to neutrality (Sandbergo et al, 1965). The silicic acid is dried in an oven at $120^{\circ} \mathrm{C}$ for 24 hours and then passed through a nylon sieve of $0.1 \mathrm{~mm}$ mesh size. It may be stored for at least three months.

PURIFICATION OF ANION EXCHANGE RESIN The resin XN 1006 (A26) (Lennig Chemicals, Bedford Row, London, WC1) is washed on a을 sintered glass funnel successively with 10 volumes each of water, ethanol, hexane, ethanol, and water. It is stored in $0.2 \mathrm{M}$ ammonium carbonate.

THIN-LAYER CHROMATOGRAPHY

To obtain sufficient separation, particularly of chenodeoxycholic acid and its stereoisomer, $\frac{C}{\Phi}$ deoxycholic acid, chromatography is carried $\stackrel{\infty}{+}$ out on plates $50 \mathrm{~cm}$ in length. The width is 0 $20 \mathrm{~cm}$. These are spread with a slurry of $15 \mathrm{~g} \overline{0}$ silicic acid and $30 \mathrm{ml}$ distilled water containing Rhodamine 6 G (BDH Ltd) $0.005 \% \mathrm{w} / \mathrm{v}$. A Shandon Unoplan spreader is used, set to give $\frac{-}{\sigma}$ a layer $0.3 \mathrm{~mm}$ in thickness. Plates are divided into seven lanes.

Solvents (BDH Ltd) are redistilled befores use, with the exception of di-isopropyl ether $\frac{0}{\partial}$ Received for publication 17 July 1969. 


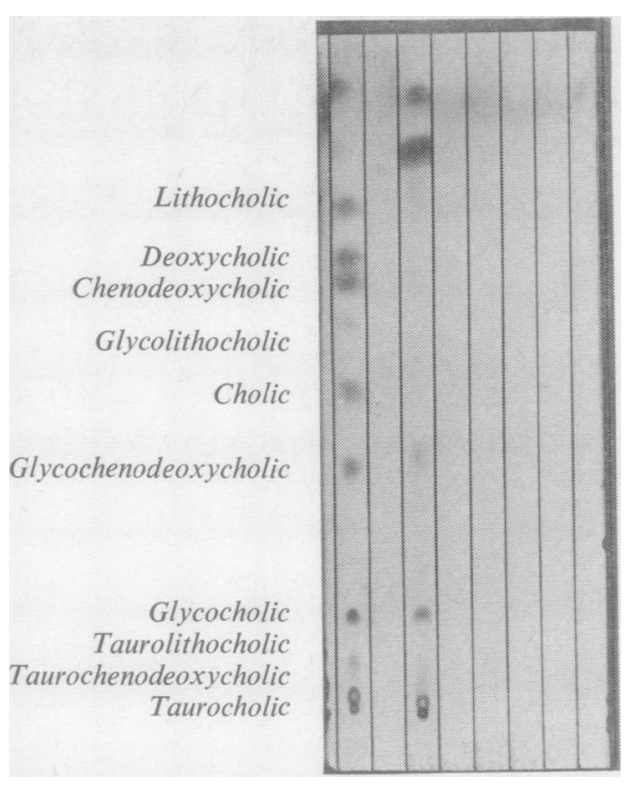

Fig. 1 Thin-layer chromatogram of standard bile acid mixture (left) and of bile acid fraction from serum of a patient with obstructive jaundice after running first and second solvent systems. Note incomplete resolution of taurine conjugates.

which is stored in the dark but used without prior treatment. Solvent covers the bottom of the tank, which is lined with filter paper to ensure saturation with solvent vapour. A small trough of freshly prepared solvent is placed in the tank; the thin-layer plate stands in this trough.

Samples of $50 \mu \mathrm{l}$ serum extract or $10 \mu \mathrm{l}$ intestinal content or bile are applied using a Hamilton syringe fitted with a 'point style 3' needle, avoiding disturbance of the silica layer. The sample is applied within an area $5-6 \mathrm{~mm}$ in diameter. One lane serves as a blank; to another lane is applied $20 \mu \mathrm{l}$ of a standard nbutanolic solution containing $1 \mu \mathrm{g} / \mu \mathrm{l}$ of each of eight bile acids; these are taurocholic, taurochenodeoxycholic, glycocholic, and glycochenodeoxycholic acids (Maybridge Research Chemicals Tintagel, N. Cornwall), and cholic, chenodeoxycholic, deoxycholic, and lithocholic acids (Steraloids, Croydon, Surrey). ${ }^{1}$

The plate is developed successively in three solvent systems. In the first solvent, chloroform, the less polar lipids, including cholesterol and triglycerides, move at or near the solvent front, while bile acids remain at the origin; a measure of purification is thus achieved. To shorten the running time to about two hours this may be

${ }^{1}$ More recently we have included a taurolithocholic acid standard and routinely determined this acid.

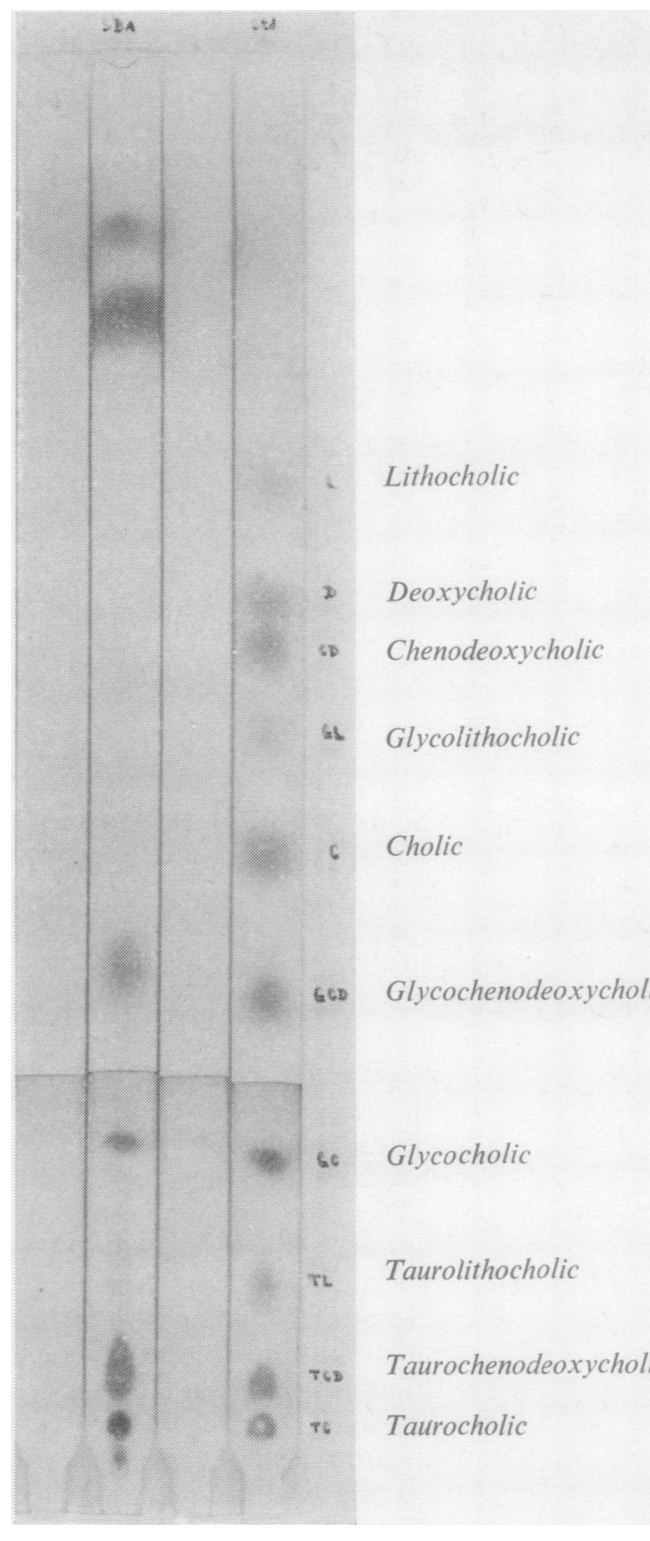

Fig. 2 Thin-layer chromatogram of bile acid standards (right hand lane) and bile acid extract from serum of patient with obstructive jaundice after third solvent. Spray reagent: $10 \%$ ethanolic phospho- $-\mathbb{\omega}$ molybdic acid.

carried out by the descending technique; the solvent is supplied to the plate by a wick of Whatman no. 1 paper, held in place by a thira glass plate, $20 \times 1 \mathrm{~cm}$, which is fastened bof a plastic-covered Terry clip at either side.

The second solvent consists of 2, 2, 4-trimethy pentane/di-isopropyl ether/acetic acid/iso-prop? anol, 2:1:1:1 by volume (Gregg, 1966). De? velopment is carried out by the ascending methof overnight, ie, about 15 hours. Less satisfactor 
separations were obtained by descending chromatography. Free bile acids and glycine conjugates are well separated, with complete resolution of deoxycholic and chenodeoxycholic acids, but taurine conjugates, which have a relatively low $\mathbf{R}_{\mathbf{f}}$, are not well separated (Fig. 1).

After air-drying, the plate is exposed for five minutes to iodine vapour and then viewed under ultraviolet light $(350 \mathrm{~m} \mu)$. This affords an extremely sensitive method for detecting several classes of organic substance (Milborrow, 1965), possibly dependent on the strong absorption of ultraviolet light by iodine reversibly bound to the spots. The free bile acids and glycochenodeoxycholic acid spots are marked, and corresponding areas are outlined in the blank lane.

After the iodine has completely sublimed, the third chromatographic system is used to separate the taurine conjugates. Each lane is 'wedged' (see Fig. 2) at the origin; this enhances the separation. A short ascending run is carried out with the system propionic acid/iso-amyl acetate/water/n-propanol, $3: 4: 1: 2$ by volume (Hofmann, 1961). Development is stopped when the solvent front has reached a point $2 \mathrm{~cm}$ below the glycochenodeoxycholic acid spots. Taurine conjugates and glycocholic acid are then located as before.

\section{QUANTITATION}

Sample, standard, and blank spots are scraped into $130 \times 17 \mathrm{~mm}$ glass-stoppered tubes. To each is added $2 \mathrm{ml}$ concentrated sulphuric acid (Analytical Reagent, BDH Ltd) for analysis of serum, $4 \mathrm{ml}$ for intestinal contents. The silica is thoroughly dispersed, using a vortex mixer, and the stoppered tubes are heated at $60^{\circ} \mathrm{C}$ for one hour in a water bath withut further mixing.

\begin{tabular}{lllll}
\hline Bile Acid & $\begin{array}{l}\text { No. of } \\
\text { Observations }\end{array}$ & $\begin{array}{l}\text { Recovery } \\
(\mu \mathrm{g})\end{array}$ & $\begin{array}{l}\text { Recovery } \\
\text { (range\%) }\end{array}$ & $\begin{array}{l}\text { Recovery } \\
(\text { mean \%) }\end{array}$ \\
\hline Taurocholic & 7 & $7 \cdot 7-10 \cdot 8$ & $77-108$ & 92 \\
Taurochenodeoxycholic & 7 & $8 \cdot 3-10 \cdot 2$ & $83-102$ & 92 \\
Glycocholic & 7 & $8 \cdot 4-10 \cdot 0$ & $84-100$ & 94 \\
Glycochenodeoxycholic & 6 & $8 \cdot 2-10 \cdot 3$ & $82-103$ & 97 \\
Cholic & 7 & $9 \cdot 1-10 \cdot 4$ & $91-104$ & 97 \\
Chenodeoxycholic & 7 & $8 \cdot 3-9 \cdot 8$ & $83-98$ & 91 \\
Deoxycholic & 7 & $9 \cdot 0-10 \cdot 4$ & $90-104$ & 97 \\
Lithocholic & 7 & $9 \cdot 3-10 \cdot 4$ & $93-104$ & 98 \\
\hline
\end{tabular}

Table 1 Recovery of $10 \mu g$ quantities of bile acids added to samples of intestinal juice

\begin{tabular}{lllll}
\hline Bile Acid & $\begin{array}{l}\text { No. of } \\
\text { Observations }\end{array}$ & $\begin{array}{l}\text { Recovery } \\
(\mu g)\end{array}$ & $\begin{array}{l}\text { Recovery } \\
\text { (range \%) }\end{array}$ & $\begin{array}{l}\text { Recovery } \\
(\text { mean \%) }\end{array}$ \\
\hline Taurocholic & 6 & $14 \cdot 2-17 \cdot 0$ & $71-85$ & 77 \\
Taurochenodeoxycholic & 6 & $14 \cdot 0-16 \cdot 2$ & $70-81$ & 76 \\
Glycocholic & 6 & $15 \cdot 6-18 \cdot 6$ & $78-93$ & 78 \\
Glycochenodeoxycholic & 6 & $13 \cdot 6-15 \cdot 8$ & $68-79$ & 74 \\
Cholic & 6 & $14 \cdot 8-20 \cdot 8$ & $74-104$ & 90 \\
Chenodeoxycholic & 6 & $15 \cdot 6-19 \cdot 4$ & $78-97$ & 87 \\
Deoxycholic & 6 & $13 \cdot 8-17 \cdot 8$ & $69-89$ & 80 \\
Lithocholc & 6 & $14 \cdot 8-18 \cdot 4$ & $74-92$ & 82 \\
\hline
\end{tabular}

Table II Recovery of $20 \mu \mathrm{g}$ quantities of bile acids added to serum
They are then centrifuged at $3,000 \mathrm{rpm}$ for 30 minutes at $4^{\circ} \mathrm{C}$; at this temperature the fluorescence is stable for at least 24 hours.

Fluorimetry is carried out in a spectrophoto fluorimeter (Aminco-Bowman), using a xenor arc. Peak excitation was found to be at $470 \mathrm{~m} \mu$. and the fluorescence peak was at $490 \mathrm{~m} \mu \stackrel{\vec{F}}{\vec{F}}$ Excitation has also been carried out at lowe 6 wavelengths with limited loss of sensitivity듬 eg, using the $436 \mathrm{~m} \mu$ mercury line. The Locarte LFM $/ 5$ fluorimeter has also been found satis factory; a zinc lamp is used, with an LF 1 l primary filter. The fluorescent band is selected ${ }^{\text {? }}$ by an LF 7 filter, and a monochromator setting $\overrightarrow{0}$ of $525 \mathrm{~m} \mu$ was found optimal in our instrument $-\vec{H}$ One millilitre of sulphuric acid is then used for both serum and intestinal content.

SERUM BILE ACIDS

A bile acid fraction is isolated from 2 to $10 \mathrm{~m}$ samples of serum, essentially by the procedures of Sandberg et al (1965). The resin is slurried in $0.2 \mathrm{M}$ ammonium carbonate and added to $10 \mathrm{~mm}$ ID chromatography column to a heighe् of $10 \mathrm{~cm}$. It is washed successively with $500 \mathrm{ml}$ volumes of $1 \mathrm{~N}$ aqueous sodium hydroxide, of $1 \mathrm{~N}$ sodium hydroxide in $80 \%$ ethanol, and of water until the wash is neutral. The sample of serum (2-10 $\mathrm{ml}$ depending on the expected biles acid concentration) is diluted $1: 1$ with waterō and the $p \mathrm{H}$ adjusted to 11 with $1 \mathrm{~N} \mathrm{NaOH}$. Theڤ column is eluted with $20 \mathrm{ml} 95 \%$ ethanol, $40 \mathrm{mb}$ ethylene chloride-ethanol mixture $(1: 1 \mathrm{v} / \mathrm{v}), \overrightarrow{\bar{\sigma}}$ and $20 \mathrm{ml} 80 \%$ ethanol which are discarded.3 The anionic fraction is then eluted with $150 \mathrm{ml}$. $0.2 \mathrm{M}$ ammonium carbonate in $80 \%$ ethano and this is taken to dryness in a rotary evaporator Bile acids are transferred by means of several? washes of $n$-butanol to a pear-shaped $10 \mathrm{ml} \frac{}{3}$ flask, and the solvent is again removed on the rotary evaporator. The residue is dissolved in $\frac{0}{3}$ $100-400 \mu \mathrm{l}$ n-butanol and an aliquot of $50 \mu \mathrm{l}$ is
taken for thin-layer chromatography.

Samples of aspirate from the small intestine $\frac{D}{2}$ obtained from fasting subjects, or bile, are applied directly to the plate in amounts of $10 \mu \mathrm{l}$. N

\section{Results}

By sequential use of three chromatographic $\stackrel{\mathscr{D}}{\mathscr{C}}$ solvents satisfactory separations of taurocholic, taurolithocholic, glycocholic, glycolithocholic, $\frac{0}{0}$ cholic, deoxycholic, chenodeoxycholic, and litho- $\overrightarrow{\mathbb{D}}$ cholic acids are obtained (Fig. 2), as well as a $\frac{O}{\mathbb{D}}$ substantial degree of purification from con- $\varrho$ taminating sterois and triglycerides. Taurine $\bar{\gamma}$ conjugates of deoxycholate and chenodeoxy- 8 cholate are not resolved and are estimated음 together as taurochenodeoxycholate. Similarly glycine conjugates of dihydroxy-acids were $\stackrel{?}{?}$ 


\begin{tabular}{|c|c|c|}
\hline & Present Method & $\begin{array}{l}\text { B-Hydroxysteroid } \\
\text { Dehydrogenase Method }\end{array}$ \\
\hline 1 & $67 \cdot 0$ & 66.0 \\
\hline 2 & 15.9 & 15.0 \\
\hline 3 & $8 \cdot 3$ & 8.0 \\
\hline 4 & 9.0 & 11.0 \\
\hline 5 & 3.9 & 2.8 \\
\hline 6 & $3 \cdot 1$ & 0 \\
\hline
\end{tabular}

Table III Total serum bile acid concentrations $(\mu-\text { mole- } l)^{1}$

${ }^{1}$ Duplicate specimens were analysed by the present method and by the enzymic procedure of Iwata and Yamasaka (1964)

\begin{tabular}{|c|c|c|c|}
\hline & $\begin{array}{l}\text { Present } \\
\text { Method }\end{array}$ & $\begin{array}{l}\text { Sandberg et al } \\
(1965)\end{array}$ & $\begin{array}{l}\text { Roovers et al } \\
(1968)\end{array}$ \\
\hline $\begin{array}{l}\text { Cholic acid } \\
\text { Chenodeoxycholic \& } \\
\text { deoxycholic acids }\end{array}$ & $\begin{array}{l}0.77-2 \cdot 60 \\
0.68-1 \cdot 44\end{array}$ & $\begin{array}{l}0.05-1 \cdot 58 \\
0.51-3.02\end{array}$ & $\begin{array}{l}0 \cdot 76-1 \cdot 05 \\
2 \cdot 16-3 \cdot 80\end{array}$ \\
\hline Total & $2 \cdot 32-3 \cdot 68$ & $0 \cdot 73-4 \cdot 60$ & $2 \cdot 92-4 \cdot 35$ \\
\hline Number of samples & 12 & 15 & 3 \\
\hline
\end{tabular}

Table V Normal range of serum bile acid concentrations expressed as free bile acids ( $\mu$-mole/l)

\begin{tabular}{|c|c|c|c|c|c|c|c|c|c|c|c|c|c|c|c|}
\hline \multirow[t]{2}{*}{ Bile Acid } & \multicolumn{6}{|l|}{ Male } & \multicolumn{6}{|c|}{ Female } & \multirow[t]{2}{*}{ Mean } & \multirow{2}{*}{$\begin{array}{l}\text { Standard } \\
\text { Deviation }\end{array}$} & \multirow{2}{*}{$\begin{array}{l}\vec{\omega} \\
\text { م }\end{array}$} \\
\hline & 1 & 2 & 3 & 4 & 5 & 6 & 7 & 8 & 9 & 10 & 11 & 12 & & & \\
\hline $\begin{array}{l}\text { Taurocholic } \\
\text { Taurochenodeoxycholic } \\
\text { Glycocholic } \\
\text { Glycochenodeoxycholic }\end{array}$ & $\begin{array}{l}0 \cdot 72 \\
0 \cdot 36 \\
1 \cdot 12 \\
0 \cdot 60\end{array}$ & $\begin{array}{l}0 \cdot 52 \\
0 \cdot 40 \\
0 \cdot 47 \\
0 \cdot 83\end{array}$ & $\begin{array}{l}0 \cdot 68 \\
0 \cdot 36 \\
0 \cdot 26 \\
0 \cdot 89\end{array}$ & $\begin{array}{l}0 \cdot 45 \\
0 \cdot 30 \\
1 \cdot 72 \\
1 \cdot 41\end{array}$ & $\begin{array}{l}0 \cdot 10 \\
0 \cdot 28 \\
1 \cdot 59 \\
0 \cdot 71\end{array}$ & $\begin{array}{l}0 \cdot 31 \\
0 \cdot 24 \\
2 \cdot 14 \\
1 \cdot 27\end{array}$ & $\begin{array}{l}0 \cdot 52 \\
0 \cdot 32 \\
1 \cdot 66 \\
0 \cdot 85\end{array}$ & $\begin{array}{l}0.23 \\
0.30 \\
1.46 \\
0.96\end{array}$ & $\begin{array}{l}0.20 \\
0.44 \\
1.72 \\
0.31\end{array}$ & $\begin{array}{l}0 \cdot 20 \\
0 \cdot 20 \\
2 \cdot 79 \\
1 \cdot 05\end{array}$ & $\begin{array}{l}0 \cdot 25 \\
0 \cdot 20 \\
1 \cdot 67 \\
0 \cdot 60\end{array}$ & $\begin{array}{l}0 \cdot 39 \\
0 \cdot 20 \\
2 \cdot 15 \\
0 \cdot 80\end{array}$ & $\begin{array}{l}0.38 \\
0.30 \\
1 \cdot 57 \\
0.86\end{array}$ & $\begin{array}{l}0 \cdot 20 \\
0 \cdot 08 \\
0 \cdot 71 \\
0 \cdot 30\end{array}$ & 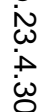 \\
\hline Total & $2 \cdot 80$ & $2 \cdot 22$ & $2 \cdot 19$ & $3 \cdot 88$ & $2 \cdot 68$ & 3.96 & $3 \cdot 35$ & 2.95 & $2 \cdot 67$ & $4 \cdot 24$ & $2 \cdot 72$ & 3.64 & $3 \cdot 11$ & 0.69 & \\
\hline $3-\mathrm{OH} / 2-\mathrm{OH}^{1}$ & 1.91 & $0 \cdot 80$ & 0.75 & 1.27 & 1.71 & 1.62 & 1.86 & $1 \cdot 34$ & $2 \cdot 56$ & $2 \cdot 39$ & $2 \cdot 40$ & 2.64 & $1 \cdot 77$ & 0.65 & \\
\hline GLY/TAU ${ }^{2}$ & 1.60 & 1.41 & $1 \cdot 13$ & $4 \cdot 17$ & 6.05 & $6 \cdot 20$ & 2.98 & 4.57 & $3 \cdot 17$ & $9 \cdot 60$ & 5.05 & $5 \cdot 17$ & $4 \cdot 27$ & $2 \cdot 44$ & \\
\hline
\end{tabular}

Table IV Fasting serum bile acid concentrations ( $\mu$-mole/l) in normal subjects

${ }^{1}$ Ratio of sum of trihydroxy-bile acid concentrations (taurocholic, glycocholic, and cholic acids) to dihydroxy-bile acid concentrationse (taurochenodeoxycholic, taurodeoxycholic, glycochenodeoxycholic, glycodeoxycholic, deoxycholic, and chenodeoxycholic acids).

${ }^{2}$ Ratio of total glycine conjugates to total taurine conjugates.

estimated as glycochenodeoxycholate as their resolution was not sufficient for separate quantitation.

The mean recovery of bile acids added to intestinal juice (Table I) was $94 \%$, ranging from 90 to $98 \%$ for individual bile acids. Recovery of bile acids added to serum and carried through the entire analytical procedure is shown in Table II; the mean was $82 \%$.

The precision of the estimation was examination by conducting duplicate analysis of all the constituent bile acids of eight sera. The levels found varied from below $1 \mu$-mole/l to over $50 \mu \mathrm{M}$ and the 40 pairs of results have therefore been divided into three groups: (1) values below $3 \mu$-mole/l, ie, within the normal range; (2) values between 3 and $10 \mu$-mole $/ 1$; and (3) values greater than $10 \mu$-mole/l.

The standard deviation of a single estimation, calculated as

$$
S=\sqrt{\frac{\Sigma \mathrm{d}^{2}}{2 \mathrm{~N}}}
$$

where $\mathrm{d}=$ difference between duplicates and $\mathrm{N}=$ number of pairs was $0 \cdot 27,0 \cdot 71$, and $2 \cdot 16$ $\mu$-mole/l respectively, giving a coefficient of variation of about $10 \%$.

To test the specificity of the procedure, six duplicate specimens of serum were analysed for bile acids by the method of Iwata and Yamasaki (1964) which depends on oxidation of bile acids by the enzyme $\beta$-hydroxysteroid dehydrogenase. The findings are compared in Table III with those obtained by the present method; there iso reasonable agreement at higher bile acid con $\frac{0}{8}$ centrations, and the discrepancies at lower 2 concentrations may be explicable on the lessero를 sensitivity of the enzymatic procedure as compared with fluorimetery.

To determine the lower limit of sensitivity of the method, the mean and standard deviation of the blank reading were calculated for 14 thinlayer plates. The standard deviation did noB exceed $25 \%$ of the mean blank. Bile acid fluorescence which does not exceed $50 \%$ of the blank fluorescence on the same plate is therefore $\mathrm{re}_{-}$ garded as insignificant. When using a plasma sample of $10 \mathrm{ml}$ and dissolving the bile aciot fraction in $100 \mu \mathrm{l}$-butanol the lower limits of sensitivity are: taurocholic acid $0.12 \mu$-mole/1 N taurochenodeoxycholic acid $0 \cdot 12 \mu$-mole/l, glyco $N$ cholic acid $0 \cdot 28 \mu$-mole/l, glycochenodeoxycholion acid $0.27 \mu$-mole $/ 1$, cholic acid $0.31 \mu$-mole $/ 1_{\sigma}^{\omega}$ chenodeoxycholic acid $0 \cdot 19 \mu$-mole/1, deoxycholiz acid $0.14 \mu$-mole/1, and lithocholic acid 0.36 $\mu$-mole/l.

The range of bile acid concentrations in 12 samples of fasting peripheral blood serum (obtained from healthy laboratory personnel) isD shown in Table IV. There was no evident sex? difference. Free bile acids were not detectable? Our data, when recalculated as free cholic acide and free dihydroxy acids, correspond fairly? closely with those reported by Sandberg et aP (1965) and Roovers et al (1968), who used gase liquid chromatography (Table V). 


\begin{tabular}{|c|c|c|c|c|c|c|}
\hline \multirow[t]{3}{*}{ Bile Acid } & \multicolumn{3}{|l|}{ Diagnosis } & \multicolumn{3}{|c|}{ Polya Partial Gastrectomy } \\
\hline & \multirow{2}{*}{$\begin{array}{l}\text { Case } 1 \\
\text { Duodenal } \\
\text { Sample }\end{array}$} & \multicolumn{2}{|l|}{ Case 2} & \multirow{2}{*}{$\begin{array}{l}\text { Case } 3 \\
\text { Jejunal } \\
\text { Sample }\end{array}$} & \multirow{2}{*}{$\begin{array}{l}\text { Case } 4 \\
\text { Jejunal } \\
\text { Sample }\end{array}$} & \multirow{2}{*}{$\begin{array}{l}\text { Case } 5 \\
\text { Jejunal } \\
\text { Sample }\end{array}$} \\
\hline & & $\begin{array}{l}\text { Duodenal } \\
\text { Sample }\end{array}$ & $\begin{array}{l}\text { Jejunal } \\
\text { Sample }\end{array}$ & & & \\
\hline Taurocholic & 0.08 & 0.12 & - & $1 \cdot 1$ & 0.37 & 0.83 \\
\hline Taurochenodeoxycholic & 0.81 & 0.01 & - & $2 \cdot 3$ & 0.90 & $3 \cdot 1$ \\
\hline Glycocholic & $6 \cdot 5$ & 2.80 & 0.20 & $6 \cdot 2$ & 1.00 & $4 \cdot 6$ \\
\hline Glycochenodeoxycholic & $10 \cdot 7$ & $1 \cdot 70$ & 0.20 & $6 \cdot 3$ & $4 \cdot 00$ & $9 \cdot 6$ \\
\hline Cholic & 6.7 & 0.20 & $2 \cdot 20$ & $0 \cdot 21$ & $0 \cdot 16$ & 0.44 \\
\hline Chenodeoxycholic & $2 \cdot 7$ & - & 0.23 & 0.08 & - & - \\
\hline Deoxycholic & $4 \cdot 2$ & - & - & - & - & - \\
\hline Lithocholic & - & - & - & - & - & - \\
\hline Total bile acids & $31 \cdot 7$ & $4 \cdot 83$ & $2 \cdot 83$ & $16 \cdot 1$ & 6.53 & $18 \cdot 6$ \\
\hline Free bile acids & $13 \cdot 6$ & $0 \cdot 20$ & 2.43 & 0.29 & $0 \cdot 16$ & 0.44 \\
\hline
\end{tabular}

Table Vl Bile acids (m-mole/l) in small intestinal aspirates from patients with malabsorption

\begin{tabular}{|c|c|c|c|c|c|c|c|c|c|}
\hline \multirow[t]{3}{*}{ Bile Acid } & \multirow{3}{*}{$\begin{array}{l}\text { Normal } \\
\text { Range }\end{array}$} & \multicolumn{8}{|c|}{ Diagnosis } \\
\hline & & \multicolumn{2}{|c|}{ Hepatitis } & \multicolumn{2}{|c|}{$\begin{array}{l}\text { Intrahepatic } \\
\text { Cholestasis }\end{array}$} & \multicolumn{2}{|c|}{$\begin{array}{l}\text { Extrahepatic } \\
\text { Obstructive Jaundice }\end{array}$} & \multirow{2}{*}{$\begin{array}{l}\text { Cirrhosis } \\
\text { Case } 7\end{array}$} & \multirow{2}{*}{$\begin{array}{l}\text { Massive Intestinal } \\
\text { Resection }\end{array}$} \\
\hline & & Case 1 & Case 2 & Case 3 & Case 4 & Case 5 & Case 6 & & \\
\hline \multirow{12}{*}{$\begin{array}{l}\text { Bilirubin }(\mathrm{mg} / 100 \mathrm{ml}) \\
\text { Taurocholic } \\
\text { Taurochenodeoxycholic } \\
\text { Glycocholic } \\
\text { Glycochenodeoxycholic } \\
\text { Cholic } \\
\text { Chenodeoxycholic } \\
\text { Deoxycholic } \\
\text { Lithocholic } \\
\text { Total bile acids } \\
\text { 3-OH/2-OH } \\
\text { GLY/TAU }\end{array}$} & $0 \cdot 1-0.8$ & $11 \cdot 00$ & $4 \cdot 5$ & $3 \cdot 0$ & 1.6 & 10 & $5 \cdot 2$ & $1 \cdot 2$ & 0.6 \\
\hline & $0 \cdot 10-0 \cdot 72$ & $50 \cdot 4$ & $20 \cdot 6$ & $56 \cdot 3$ & 9.08 & $19 \cdot 0$ & 2.9 & $8 \cdot 15$ & 0.23 \\
\hline & $0.20-0.44$ & $19 \cdot 5$ & $34 \cdot 2$ & $56 \cdot 7$ & 9.65 & $17 \cdot 3$ & $78 \cdot 4$ & $2 \cdot 81$ & 0.30 \\
\hline & $0 \cdot 26-2 \cdot 79$ & $34 \cdot 3$ & $58 \cdot 8$ & $16 \cdot 3$ & $4 \cdot 55$ & $45 \cdot 7$ & $65 \cdot 0$ & $11 \cdot 8$ & 0.75 \\
\hline & $0.31-1.41$ & $20 \cdot 7$ & $35 \cdot 0$ & 25.9 & 2.99 & $2 \cdot C 1$ & $73 \cdot 0$ & $28 \cdot 8$ & 0.51 \\
\hline & - & $1 \cdot 56$ & $2 \cdot 44$ & $1 \cdot 54$ & $2 \cdot 44$ & 0.46 & $2 \cdot 2$ & 1.59 & 2.69 \\
\hline & - & - & & 0.71 & $4 \cdot 19$ & 0.46 & - & 0.41 & $6 \cdot 39$ \\
\hline & - & - & - & - & - & - & - & - & - \\
\hline & - & - & - & - & - & - & - & - & - \\
\hline & $2 \cdot 2-4 \cdot 2$ & 140.5 & $151 \cdot 0$ & $157 \cdot 4$ & $32 \cdot 9$ & 84.9 & $280 \cdot 5$ & $54 \cdot 6$ & 10.9 \\
\hline & $0 \cdot 75-2 \cdot 64$ & $2 \cdot 15$ & $1 \cdot 18$ & 0.89 & 0.95 & $3 \cdot 29$ & 0.87 & 0.65 & 0.51 \\
\hline & $1 \cdot 13-9 \cdot 6$ & 0.79 & $1 \cdot 71$ & 0.37 & 0.40 & $1 \cdot 31$ & 0.97 & $3 \cdot 7$ & $2 \cdot 4$ \\
\hline
\end{tabular}

Table VII Serum bile acids ( $\mu$-mole/l) in jaundice and the stagnant loop syndrome

ILLUSTRATIVE CLINICAL OBSERVATIONS The concentration of conjugated and free bile acids in the intestinal contents of five patients with intestinal malabsorption is shown in Table VI.

Patients 1 and 2 had massive duodenal and jejunal diverticulosis with bacterial colonization of the small intestine. Both patients had severe steatorrhoea with faecal fat excretion of 22 to $30 \mathrm{~g} /$ day. In patient 1 , duodenal juice contained the free bile acids, cholic, chenodeoxycholic, and deoxycholic acid; patient 2 , who in addition had malnutrition and hypoproteinaemia, had lower levels of total bile acids in the jejunal sample in which the main bile acid was cholic acid (Tabaqchali, Hatzioannou, and Booth, 1968).

In patients 3,4 , and 5 , who had undergone Polya partial gastrectomy and had minimal steatorrhoea, the bile acids were present in greater concentration, and almost entirely in the conjugated form. Lithocholic acid was not detectable in any of these specimens.

Serum bile acid measurements in patients with jaundice of various types, and in a patient who had had a massive intestinal resection, are shown in Table VII. All patients with hepatobiliary disease (1-7) had a marked increase in fasting serum bile acid concentrations, and the bile acids were present mainly in the conjugated form. Patients 1 and 2 had viral hepatitis. Serial bile acid measurements were carried out in patient 1 (Fig. 3). Patient 3 had primary biliary cirrhosis, and patient 4 had intrahepatic cholestasis associated with ulcerative colitis. 3 A striking finding in patients 3 and 4 was the decrease in the glycine/taurine ratio in serum bile acids. Patients 5 and 6 had extrahepatic 0

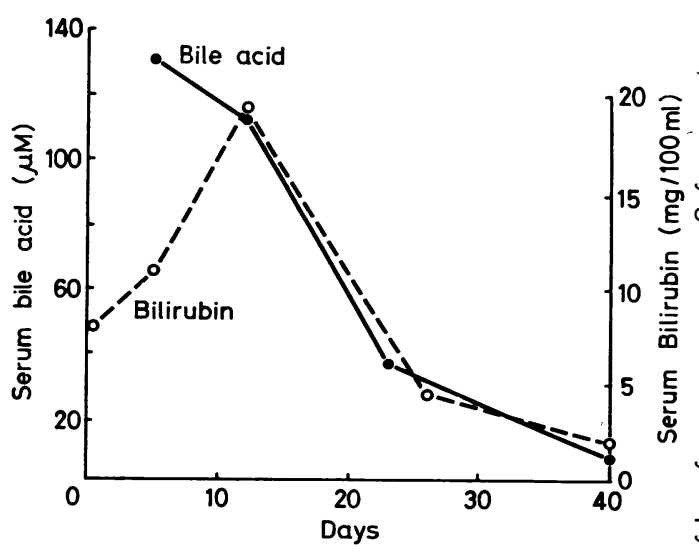

Fig. 3 Serial measurements of total serum bile acid concentrations in a patient with viral hepatitis. 
obstructive jaundice due to carcinoma of the head of the pancreas, and patient 7 had alcoholic cirrhosis. The ratio of trihydroxy to dihydroxy bile acids varied considerably, and no consistent trend is as yet evident. Patient $\mathbf{8}$ had undergone massive intestinal resection following thrombosis of the mesenteric vessels, leaving only $14 \mathrm{in}$. of proximal jejunum which was anastomosed to the transverse colon. He also had bacterial colonization of the jejunal remnant. In contrast to the patients with hepatobiliary disease, the serum bile acids in this patient consisted chiefly of free acids. The free bile acids present were cholic and chenodeoxycholic acid. Deoxycholic and lithocholic acids were not found. The ratio of trihydroxy to dihydroxy bile acids was low, as we have observed in seven out of eight patients with intestinal resections or with the stagnant loop syndrome (Panveliwalla, 1968).

\section{Discussion}

The procedure described has been in use in this laboratory for two years; the accuracy appears to be good, and the precision is adequate. The sensitivity is such as to permit the determination even of subnormal concentrations.

In samples of $10 \mathrm{ml}$ normal serum, only glycocholic, glycochenodeoxycholate, taurocholic, and taurochenodeoxycholate were detected, confirming the results of Sandberg et al (1965). In serum from jaundiced patients, not only may abnormal patterns of conjugates be shown, but free acids may be detected in measurable amounts.

By permitting the individual measurement of the conjugated and free bile acids of serum, the present relatively simple method may extend the value of bile acid studies in the investigation of hepatobiliary and intestinal disease.
We thank Professor C. C. Booth for his encouragement, and for allowing us to study the patients undef. his care. We are grateful to Dr G. Ellard for permit ting us to use the spectrofluorimeter in his laboratoryou The work was supported in part by a grant from the Medical Research Council.

\section{References}

Gregg, J. A. (1966). New solvent systems for thin-layer chroma tography of bile acids. J. Lipid Res., 7, 579-581.

Hofmann, A. F. (1962). Thin-layer adsorption chromatograph of free and conjugated bile acids on silicic acid.J. Lipid Res., 3, 127-129.

Iwata, T., and Yamasaki, K. (1964). Enzymatic determination and thin-layer chromatography of bile acids in blood? J. Biochem. 56, 424-431.

Kottke, B. A., Wollenweber, J., and Owen, C. A., Jr. (1966) Quantitative thin-layer chromatography of free an\& conjugated cholic acid in human bile and duodenat contents. J. Chromatog., 21, 439-447.

Milborrow, B. V. (1965). Iodine quenched fluorescence, a sensitivis non-destructive method for the detection of organic compounds on chromatoplates. J. Chromatog., 19, 194-197.

Panveliwalla, D. (1968). Unpublished observations.

Roovers, J., Evrard, E., and Vanderhaeghe, H. (1968). A®D improved method for measuring human blood bile acid Clin chim. Acta, 19, 449-457.

Rudman, D., and Kendall, F. E. (1957). Bile acid content of human serum. I. Serum bile acids in patients with hepatie disease. J. clin. Invest., 36, 530-537.

Sandberg, D. H., Sjövall, J., Sjövall, K., and Turner, D. A. (1965). Measurement of human serum bile acids b gas-liquid chromatography. J. Lipid Res., 6, 182-192.

Sjövall, J. (1959). The determination of bile acids in bile an $\Phi$ duodenal contents by quantitative paper chromatography:bile acids and steroids 71. Clin. chim. Acta, 4, 652-664.

Tabaqchali, S., Hatzioannou, J., and Booth, C. C. (1968). Bile salt deconjugation and steatorrhoea in patients with the stagnant-loop syndrome. Lancet, 2, 12-16.

Wootton, I. D. P., and Osborn, E. C. (1960). A method fở estimating bile acids in blood. Mem. Soc. Endocrinol., 8 70-76. 